Research Paper

\title{
Aberrant DNA methylation of the pl6, APC, MGMT, TIMP3 and CDHI gene promoters in tumours and the surgical margins of patients with oral cavity cancer
}

\author{
Joanna Katarzyna Strzelczyk ${ }^{1 凶}$, Łukasz Krakowczyk², Aleksander Jerzy Owczarek ${ }^{3}$ \\ 1. Department of Medical and Molecular Biology, School of Medicine with the Division of Dentistry in Zabrze, Jordana 19 Str., $41-808$ Zabrze, Medical \\ University of Silesia in Katowice, Zabrze, Poland \\ 2. Clinic of Oncological and Reconstructive Surgery, Maria Sklodowska-Curie Memorial Cancer Center and Institute of Oncology, Gliwice Branch, Wybrzeże \\ Armii Krajowej 15 Str., 44-101 Gliwice, Poland \\ 3. Department of Statistics, Department of Instrumental Analysis, School of Pharmacy with the Division of Laboratory Medicine in Sosnowiec, Ostrogórska 30 \\ Str., 41-200 Sosnowiec, Medical University of Silesia in Katowice, Sosnowiec, Poland
}

$\square$ Corresponding author: Joanna Katarzyna Strzelczyk, Department of Medical and Molecular Biology, School of Medicine with the Division of Dentistry in Zabrze, Medical University of Silesia in Katowice, Jordana 19 Str., 41-808 Zabrze, Poland, tel./fax +48 322722171, jstrzelczyk@sum.edu.pl; asia.strzelczyk @gmail.com

(c) Ivyspring International Publisher. This is an open access article distributed under the terms of the Creative Commons Attribution (CC BY-NC) license (https://creativecommons.org/licenses/by-nc/4.0/). See http://ivyspring.com/terms for full terms and conditions.

Received: 2017.12.21; Accepted: 2018.03.10; Published: 2018.04.27

\begin{abstract}
Oral cavity cancer is a type of head and neck squamous cell carcinoma (HNSCC) and contributes to significant morbidity and mortality each year. An epigenetic pathway of transcriptional inactivation for many genes has been described in various cancers, including HNSCC. For our study, we selected genes for which silencing caused by hypermethylation can promote cancer development. In 75 primary HNSCC tumours and paired surgical margins, we investigated the methylation status of the pl6, APC, MGMT, TIMP3 and CDHI gene promoters by methylation-specific PCR after bisulphite treatment. The promoter methylation rates of pl6, APC, MGMT, TIMP3 and CDHI in tumours were $58.67 \%, 49.33 \%, 58.67 \%$, $50.67 \%$, and $57.33 \%$ and $50.67 \%, 41.33 \%, 37.33 \%, 42.67 \%$, and $25.33 \%$ in the surgical margin, respectively. Our observations confirm the presence of epigenetic changes not only in the cancer cells, but also in the surrounding mucosa and represent a basis for further analysis to unravel these complicated issues. Appropriate cancer risk assessment based on epigenetic alterations in surgical margins may influence a patient's diagnosis and cure.
\end{abstract}

Key words: methylation, genes, tumour, surgical margin, oral cavity cancer, head and neck squamous cell carcinoma (HNSCC)

\section{Introduction}

Oral cavity cancer is an example of head and neck squamous cell carcinoma (HNSCC) in the head and neck area and can be defined as a malignant tumour derived from squamous epithelial cells that contributes significant morbidity and mortality each year [1]. Alcohol and tobacco abuse is recognized as an initiating element in HNSCC, and HPV infection is also defined as a preliminary factor [2-4]. Molecular alterations and aberrant signalling pathways in carcinogenesis of the head and neck have been identified [5]. As well as genetic abnormalities, epigenetic alterations have also been implicated in cancer. Epigenetic changes are defined as modified gene expression patterns caused by mechanisms that do not concerns the primary DNA sequence. Epigenetic alteration relates to gains and losses of DNA methylation and to histone modifications. Aberrant DNA methylation comprises genepromoter-specific hypermethylation and its mechanism causing loss of gene expression, and global hypomethylation as a prelude to structural changes in chromosomes, genome instability, and oncogene activation [6]. DNA methylation is an encouraging marker for past exposure to carcinogens and future risk of cancer development [7]. An epigenetic pathway of transcriptional inactivation for 
many genes has been described in various cancers [8-11]. Other publications address epigenetic changes in HNSCC cancers [10,12-17], but few have compared the methylation level of tumours vs surgical margins [18-20]. Promoter hypermethylation in tissue samples can be detected by many molecular methods $[11,18$, $21,22]$ including methylation-specific polymerase chain reaction (MSP) [23, 24]. In our study, we analysed samples of tumours and paired surgical margins to examine the promoter methylation status of p16, APC, MGMT, TIMP3 and CDH1 genes. All these genes are known to participate in the oncogenic pathway and to show tumour suppressor activities. We also evaluated the association of promoter methylation of these genes with clinicopathological features, habitual factors, metastasis, tumour recurrence rate, and 5-year survival rate of patients.

\section{Materials and Methods}

\section{Study population}

We studied 75 patients with primary tumours in the oral cavity. There were 50 men and 25 women, with a mean age of $56 \pm 11$ years. There was no difference in age between men and women ( $55 \pm 12$ vs $56 \pm 81, p=0.708)$. All of the patients were graded by the TNM staging system. Of the 75 patients, 4 (5.3\%) were in the $\mathrm{T} 1$ stage, $11(14.7 \%)$ were in the $\mathrm{T} 2$ stage, $18(24.0 \%)$ were in the T3 stage and $42(56.0 \%)$ were in the T4 stage. There was no statistically significant difference in the $\mathrm{T}$ and $\mathrm{N}$ stage distributions between men and women. Moreover, 31 (41.3\%) were in the N0 stage, $28(37.3 \%)$ were in the N1 stage, $15(20.0 \%)$ were in the N2 stage and 1 was in the N3 stage. Histologic grading was classified as grade 1 (G1, well differentiated), grade 2 (G2, moderately differentiated), and grade 3 (G3, poorly differentiated). In G1 there were $11(14.7 \%)$ subjects and in G2 there were $57(76.0 \%)$, and the rest were in G3.

In all groups, 58 (77.3\%) subjects smoke (currently), 57 (76.0\%) reported alcohol intake and 30 $(40.0 \%)$ reported a family cancer episode (first-degree family history of cancer). Females smoked and drank less frequent than males ( $64.0 \%$ vs $84.0 ; \mathrm{p}<0.05$ and $52.0 \%$ vs $88.0 \% ; \mathrm{p}<0.001)$. There was no difference in previously reported family cancer episodes between men and women ( $40 \%$ in both groups). Survival rate in the analysed group was $46.7 \%$, with metastasis observed in $13.3 \%$ and tumour recurrence in $32 \%$. No patients received preoperative radio- or chemo-therapy. This study was approved by the Institutional Review Board on Medical Ethics of the Maria Sklodowska-Curie Memorial Cancer Center and Institute of Oncology in Gliwice (Nos. $\mathrm{KB} / 493-15 / 08$ and $\mathrm{KB} / 430-47 / 13$ ). All patients gave written informed consent.

\section{Tissue samples}

Samples were collected from 75 HNSCC patients with a previously untreated squamous cell carcinoma from the oral cavity at the Clinic of Oncological and Reconstructive Surgery, Maria Sklodowska-Curie Memorial Cancer Center and Institute of Oncology, Gliwice, Poland. Samples of surgical margins were obtained pair-wise from the site opposite the tumour and verified by a pathologist as free of cancer cells. Only patients who had tumour-free margins when the primary tumour was resected were included in the study. Tissue samples were quickly frozen in liquid nitrogen and stored at $-80^{\circ} \mathrm{C}$ before DNA extraction.

\section{DNA extraction and bisulphite modification}

Genomic DNA was extracted from each tumour sample and corresponding surgical margin $(20 \mathrm{mg})$ using a DNeasy Blood \& Tissue Kit (Qiagen, USA) according to the manufacturer's instructions and after tissue homogenization in a FastPrep ${ }^{\circledR}-24$ instrument using Lysing Matrix A tubes (MP Biomedicals, USA). Total DNA concentration was measured using a ND-1000 spectrophotometer (NanoDrop, USA). The gDNA was bisulphite-treated using the method described by Herman and colleagues [23]: $2 \mu \mathrm{g}$ DNA in a volume of $50 \mu \mathrm{l}$ was alkali denatured in $2 \mathrm{M}$ $\mathrm{NaOH}$ and incubated in $10 \mathrm{mM}$ hydroquinone (Sigma, USA) and 3M sodium bisulphite, $\mathrm{pH} 5.0$ (Sigma, USA) for 16 hours at $50^{\circ} \mathrm{C}$ in a microfuge tube with a mineral oil layer. Modified DNAs were purified using the Wizard DNA Clean-Up System (Promega, USA) and eluted into $50 \mu \mathrm{l}$ of sterile water. DNA was again treated with $3 \mathrm{M} \mathrm{NaOH}$, precipitated with ethanol in $3 \mathrm{M}$ sodium acetate, $\mathrm{pH} 5.2$ and resuspended in $20 \mu \mathrm{l}$ of water.

\section{Methylation-specific PCR (MSP)}

DNA methylation patterns in the CpG islands of the p16, APC, MGMT, TIMP3 and CDH1 gene promoters were determined using a methylationspecific PCR (MSP) technique following bisulphite modification of isolated genomic DNA [23]. To obtain specific PCR products, two separate PCRs were performed for each sample. "U" primers amplified only unmethylated DNA, while " $\mathrm{M}$ " primers amplified only methylated DNA in the regions of $p 16$, $A P C, M G M T$, TIMP3 and CDH1 gene promoters. Each chemically modified DNA sample was amplified with primers " $U$ " and " $M$ ", respectively. Primer sequences of gene promoters for the unmethylated reaction "' $U$ " and for the methylated reaction " $\mathrm{M}$ " with thermal cycling conditions and product size are shown in Table 1. A primer set was chosen for the promoters of selected gene sequence regions based on the 
previously published sequences in Table 1. Primers were synthesized by Genomed (Poland). Amplification of the $p 16, A P C, M G M T, T I M P 3$ and CDH1 genes was performed in $25 \mu$ of reaction mixture under the following conditions: $12.5 \mu \mathrm{PCR}$ Master Mix (Cat No. M7501; Promega, USA), $1.2 \mu \mathrm{l}$ of each primer at a concentration of $10 \mu \mathrm{M} ; 2 \mu \mathrm{l}$ of modified DNA; and $8.1 \mu \mathrm{l}$ of sterile water (Eppendorf, Germany). CpGenome Universal Methylated DNA (Chemicon Cat No. S7821) was used as a positive control for methylation, while water was used as a negative control for PCR. To verify the results, we used the EpiTec PCR Control DNA Set (Qiagen, USA, Cat No 59695) consisting of bisulphiteconverted methylated and unmethylated human DNA and unconverted unmethylated human DNA. Amplification was performed in a Mastercycler Personal thermocycler (Eppendorf, Germany). PCR products were visualized on a $2 \%$ agarose gel (Sigma, USA) with ethidium bromide (Serva, Germany) staining.

\section{Statistical analysis}

Statistical analysis was performed using STATISTICA 10.0 PL (StatSoft, QUEST, Tulsa, Oklahoma, USA). Statistical significance was set at a $p$ value below 0.1. All tests were two-tailed. Nominal and ordinal data were expressed as percentages, while interval data were expressed as mean value \pm standard deviation. Categorical variables were compared using $X^{2}$ tests. The consistency of methylation between a tumour and a margin was determined and assessed statistically with the McNemar test. For comparison of quantitative data between males and females, a parametric t-Student test was used. Distribution of variables was evaluated by the Shapiro-Wilk test, and homogeneity of variance was assessed by the Levene test. The assessment of association between clinical status, habitual factors and methylation occurrence was performed with the multivariable backward-stepwise logistic regression. Factors affecting survival, metastasis and tumour recurrence was assessed with the multivariable backward-stepwise logistic regression. Results were presented as odds ratios with confidence interval and statistical significance.

\section{Results}

Methylation of the $p 16, A P C, M G M T, T I M P 3$ and $\mathrm{CDH1}$ gene promoters was detected in tumours and surgical margins. The methylation frequency of the MGMT and CDH1 genes was significantly higher in tumours than in surgical margin tissues $(\mathrm{p}<0.01)$. The promoter methylation status of these genes in tumours and surgical margins is summarized in Table 2.

Table 1. Primer sequences and amplicon characteristics of analysed genes

\begin{tabular}{|c|c|c|c|c|}
\hline Gene & Primer sequences & $\begin{array}{l}\text { Annealing } \\
\text { temperature }\end{array}$ & $\begin{array}{l}\text { Product } \\
\text { size }\end{array}$ & Reference \\
\hline $\begin{array}{l}p 16 \\
(M)\end{array}$ & $\begin{array}{l}\text { F:TTATTAGAGGGTGGGGCG } \\
\text { GATCGC } \\
\text { R:GACCCCGAACCGCGACC } \\
\text { GTAA }\end{array}$ & $61^{\circ} \mathrm{C}-30 \mathrm{~s}$ & $150 \mathrm{bp}$ & $\begin{array}{l}\text { Wang et al. } \\
\text { [25] }\end{array}$ \\
\hline$p 16(U)$ & $\begin{array}{l}\text { F:TTATTAGAGGGTGGGGTG } \\
\text { GATTGT } \\
\text { R:CAACCCCAAACCACAAC } \\
\text { CATAA }\end{array}$ & $60^{\circ} \mathrm{C}-30 \mathrm{~s}$ & $151 \mathrm{bp}$ & $\begin{array}{l}\text { Wang et al. } \\
\text { [25] }\end{array}$ \\
\hline $\begin{array}{l}A P C \\
\text { (M) }\end{array}$ & $\begin{array}{l}\text { F:GAACCAAAACGCTCCCCA } \\
\text { T } \\
\text { R:TTATATGTCGGTTACGTGC } \\
\text { GTTTATA }\end{array}$ & $59^{\circ} \mathrm{C}-45 \mathrm{~s}$ & $74 \mathrm{bp}$ & $\begin{array}{l}\text { Righini et } \\
\text { al. [26] }\end{array}$ \\
\hline $\begin{array}{l}A P C \\
\text { (U) }\end{array}$ & $\begin{array}{l}\text { F:AAACCAAAACACTCCCCA } \\
\text { TTC } \\
\text { R:AGTTATATGTTGGTTATGT } \\
\text { GTGTTTAT }\end{array}$ & $59^{\circ} \mathrm{C}-45 \mathrm{~s}$ & $76 \mathrm{bp}$ & $\begin{array}{l}\text { Righini et } \\
\text { al. [26] }\end{array}$ \\
\hline $\begin{array}{l}\text { MGMT } \\
\text { (M) }\end{array}$ & $\begin{array}{l}\text { F:TTTCGACGTTCGTAGGTTT } \\
\text { TCGC } \\
\text { R:GCACTCTTCCGAAAACGA } \\
\text { AACG }\end{array}$ & $59^{\circ} \mathrm{C}-45 \mathrm{~s}$ & $81 \mathrm{bp}$ & $\begin{array}{l}\text { Shilpa et } \\
\text { al. [27] }\end{array}$ \\
\hline $\begin{array}{l}M G M T \\
(U)\end{array}$ & $\begin{array}{l}\text { F:TTTGTGTTTTGATGTTTGT } \\
\text { AGGTTTTTGT } \\
\text { R:AACTCCACACTCTTCCAA } \\
\text { AAACAAAACA }\end{array}$ & $59^{\circ} \mathrm{C}-45 \mathrm{~s}$ & $93 \mathrm{bp}$ & $\begin{array}{l}\text { Shilpa et } \\
\text { al. [27] }\end{array}$ \\
\hline $\begin{array}{l}\text { TIMP3 } \\
(M)\end{array}$ & $\begin{array}{l}\text { F:GCGTCGGAGGTTAAGGTT } \\
\text { GTT } \\
\text { R:CTCTCCAAAATTACCGTA } \\
\text { CGCG }\end{array}$ & $60^{\circ} \mathrm{C}-30 \mathrm{~s}$ & $116 \mathrm{bp}$ & $\begin{array}{l}\text { Righini et } \\
\text { al. [26] }\end{array}$ \\
\hline $\begin{array}{l}\text { TIMP3 } \\
(U)\end{array}$ & $\begin{array}{l}\text { F:TGTGTTGGAGGTTAAGGT } \\
\text { TGTTTT } \\
\text { R:ACTCTCCAAAATTACCAT } \\
\text { ACACACC }\end{array}$ & $59^{\circ} \mathrm{C}-1 \mathrm{~min}$ & $122 \mathrm{bp}$ & $\begin{array}{l}\text { Righini et } \\
\text { al. [26] }\end{array}$ \\
\hline $\begin{array}{l}\text { CDH1 } \\
\text { (M) }\end{array}$ & $\begin{array}{l}\text { F:TTAGGTTAGAGGGTTATC } \\
\text { GCGT } \\
\text { R:TAACTAAAAATTCACCTA } \\
\text { CCGAC }\end{array}$ & $58^{\circ} \mathrm{C}-1 \mathrm{~min}$ & $173 \mathrm{bp}$ & $\begin{array}{l}\text { Righini et } \\
\text { al. [26] }\end{array}$ \\
\hline $\begin{array}{l}\text { CDH1 } \\
(U)\end{array}$ & $\begin{array}{l}\text { F:TAATTTTAGGTTAGAGGG } \\
\text { TTATTG } \\
\text { R:CACAACCAATCAACAAC } \\
\text { ACA }\end{array}$ & $58^{\circ} \mathrm{C}-1 \mathrm{~min}$ & $173 \mathrm{bp}$ & $\begin{array}{l}\text { Righini et } \\
\text { al. [26] }\end{array}$ \\
\hline
\end{tabular}

Table. 2. Promoter methylation frequency of $p / 6, A P C, M G M T, T I M P 3$ and $C D H I$ genes in tumour and surgical margin in oral cavity patients

\begin{tabular}{|c|c|c|c|c|c|c|c|}
\hline \multirow[t]{2}{*}{ Gene } & \multicolumn{3}{|c|}{ Tumour } & \multicolumn{3}{|c|}{ Margin } & \multirow{2}{*}{$\begin{array}{l}\text { p-value } \\
\mathbf{P}\end{array}$} \\
\hline & Total & Methylation & Frequency (\%) & Total & Methylation & Frequency $(\%)$ & \\
\hline$p 16$ & 75 & 44 & 58.67 & 75 & 38 & 50.67 & 0.325 \\
\hline$A P C$ & 75 & 37 & 49.33 & 75 & 29 & 41.33 & 0.188 \\
\hline MGMT & 75 & 44 & 58.67 & 75 & 28 & 37.33 & $<0.01$ \\
\hline TIMP3 & 75 & 38 & 50.67 & 75 & 32 & 42.67 & 0.326 \\
\hline $\mathrm{CDH1}$ & 75 & 43 & 57.33 & 75 & 19 & 25.33 & $<0.001$ \\
\hline
\end{tabular}


Moreover, we investigated the clinical and habitual factors associated with methylation occurrence. In the APC gene we observed that positive nodal status conferred a higher methylation rate in matched margin samples (OR=1.66; 95\% CI: 0.92-3.01; $\mathrm{p}<0.1)$. Habitual factors linked to cigarettes were associated with higher methylation of the APC gene in tumour samples (OR=3.60; 95\% CI: 0.97-13.39; $\mathrm{p}<0.1)$. MGMT methylation was diminished in tumour samples (OR=0.38; 95\% CI: 0.13-1.06; $\mathrm{p}<0.1)$ and in margin samples from females $(\mathrm{OR}=0.23 ; 95 \% \mathrm{CI}$ : 0.06-0.84; $\mathrm{p}<0.05)$. Patients with a family history of cancer showed more frequently methylated MGMT genes in tumour samples (OR=3.04; 95\% CI: 1.08-8.55; $\mathrm{p}<0.05)$. We noted that advanced tumour stage was associated with a higher frequency of methylation of this gene in matched surgical margin samples $(\mathrm{OR}=1.78 ; \quad 95 \% \quad \mathrm{CI}:$ 0.98-3.24; $\mathrm{p}<0.1)$. However, patients with a history of abusing alcohol showed lower MGMT promoter methylation in the surgical margin (OR=0.13; 95\% CI: 0.03-0.56; $\mathrm{p}<0.01)$. Analysis of the TIMP3 gene showed that the female gender conferred a higher methylation level in margin samples (OR=2.49; 95\% CI: 0.89-6.95; $\mathrm{p}<0.1)$ and a positive $\mathrm{N}$ stage showed a higher methylation level in tumour samples (OR=1.79; 95\% CI: 0.96-3.35; $\mathrm{p}<0.1)$. For the $C D H 1$ gene, an increased methylation level was seen in tumour samples from females $(\mathrm{OR}=2.61$; 95\% CI: 0.88-7.73; $\mathrm{p}<0.1)$ and smoking was associated with higher $C D H 1$ methylation both in tumour $(\mathrm{OR}=3.13 ; 95 \% \mathrm{CI}: 0.91-10.80 ; \mathrm{p}<0.1)$ and margin samples (OR=7.12; 95\% CI: 0.87-59.36; $\mathrm{p}<0.1$ ).

Patients with an advanced $\mathrm{T}$ classification were significantly associated with a increased risk of death $(\mathrm{OR}=9.64 ;$ 95\% CI: 2.07-44.87; $\mathrm{p}<0.01)$. Disease recurrence was significantly related to female gender $(\mathrm{OR}=0.22 ; 95 \% \mathrm{CI}: 0.06-0.78 ; \mathrm{p}<0.05)$ and showed a trend towards a lower recurrence rate. No association was observed between metastasis, recurrence, or survival rate and hypermethylation of any of the genes analysed. Moreover, aberrant promoter hypermethylation of all five genes (CpG Island Methylator Phenotype, CIMP-positive) was found in tumour samples in four cases $(5.3 \%)$.

\section{Discussion}

\section{pl6}

$p 16^{I N K 4 a}(C D K N 2 A)$ is one of the most extensively studied genes in cancer, including epigenetic alterations. Hypermethylation of $p 16$ has been observed in many tumour types e.g., colon, breast, brain, kidney, pancreas, liver [28] and also in HNSCC in several studies [12, 16, 19, 24, 28-31], not only in tumour tissues but also in adjacent healthy mucosa
$[19,24,30,31]$. In our study, the promoter region was highly methylated in tumour tissue (58.7\%). Moreover, $42.6 \%$ of patients showed hypermethylation of this gene both in the tumour and matched surgical margin. According to our collected literature, the frequencies of hypermethylation in HNSCC tumours vary from $86.8 \%$ [31] to $82 \%$ [32], $49 \%$ [24], 36\% [12], and $27 \%$ [28] to $20 \%$ [19]. Other analyses showed a significant increase in promoter hypermethylation in tumours compared to normal control tissue from the resection margin in oral cancer [33-35]. A coherent methylation pattern was found in primary tumours and matched metastatic lymph nodes, and also in $65 \%$ of patient's plasma [24]. Interestingly, some studies showed methylation in patients with premalignant oral lesions and healthy controls [24, 29, 32]. $p 16$ hypermethylation showed no association with clinical and demographic features in our study population, as confirmed in other studies $[12,19,24,30,36-38]$. However, some reports show that promoter methylation of $p 16$ both in tumours and margins may be linked to chronic exposure to carcinogens in alcohol and tobacco [24, 39, 40]. Moreover, based on other findings, hypermethylation of p16 was associated with younger age, nodal involvement, distant metastasis, increased recurrence rate and shortened disease-free survival, suggesting it as a candidate prognostic and predictive biomarker in oropharyngeal squamous cell carcinoma $[18,29,31$, $34,39-41]$.

\section{APC}

Adenomatous Polyposis Coli $(A P C)$ is a tumour suppressor gene that, through Wnt signalling, inhibits cell proliferation [42]. In the present study, methylation of this gene ranges from $49 \%$ in tumour samples to $41 \%$ in margin samples. Independent studies also reported hypermethylation of $A P C$ in OSCC samples [36, 38, 43, 44], but Esteller et al. did not detect hypermethylation of this gene in head and neck cancers [28]. No differences between patients with HNSCC and healthy patients in methylation of the APC gene were observed by Longo et al., and surprisingly, this gene was frequently methylated in control samples [45]. Brait et al. reported that APC was methylated in $7 \%$ of DNA samples extracted from the plasma of a cancer-free population, and promoter methylation of this gene was not associated with several potential risk factors e.g., age, smoking and alcohol status, family cancer history, diet, and nutrition [46]. Other data also showed no correlation between aberrant methylation and clinical features and outcomes, such as survival [36, 38, 44]. 


\section{MGMT}

O6-methylguanine-DNA methyltransferase (MGMT) is involved in the guanine alkylation repair mechanism [47]. Expression of this gene varies between tissues and individuals [48]. Differential protein expression of MGMT between normal and cancer tissue was also confirmed [47]. Aberrant promoter hypermethylation of this gene is often observed in cancers including HNSCC $[8,12,16,19$, $28,30,47,49]$. The results in the present study demonstrated that MGMT was statistically significantly hypermethylated in tumours compared to margins $(58 \%$ versus $37 \%, \mathrm{p}<0.01)$. Aberrant promoter hypermethylation of the MGMT gene was detected in $73.7 \%$ of oral cavity cancers, with a significant difference between cases and controls, by Kordi-Tamandani et al. [17]. Martone et al. and Kato et al. observed that MGMT was hypermethylated in $50 \%$ and $56 \%$ of primary HNSCC tumours, and the results showed association of gene-specific hypermethylation status in tumours and paired surgical margins $[19,30]$. In our study, population, methylation of the MGMT gene was not associated with age, nodal status, and smoking, as confirmed in other studies [12, 19, 30]. However, Paluszczak et al. showed an association between methylation in tumour cells and lymph node involvement, and in turn Taioli et. al observed that reduced disease-free survival and reduced overall survival are associated with hypermethylation of this gene in HNSCC patients [49, 50]. Moreover, hypermethylation of MGMT is postulated as a potential prognostic biomarker [19].

\section{TIMP3}

The tissue inhibitor of metalloproteinase- 3 (TIMP3) may play a significant role in tumour development, growth and metastasis by interaction with metalloproteinases in the extracellular matrix [51]. In this study, no statistically significant differences between tumour and margin methylation levels for this gene was observed. Some results showed hypermethylation of TIMP3 in various tumour types [28, 51, 52]. Hypermethylation of this gene in HNSCC tumours and saliva samples was also observed [15, 16, 26, 53-55] but no relation between hypermethylation and clinical features was shown $[16,38,53,55]$. Furthermore, this gene was hypermethylated in exfoliated tumour cells in HNSCC patients compared to the healthy control group. Interestingly, the work of Longo et al. was the first study regarding methylation of exfoliated cells obtained from patients with non-invasive techniques, namely cytobrushes [45].

\section{CDHI}

Cadherin 1 (CDH1/E-cadherin/E-cad) is related to cell adhesion and regarded as an invasion-suppressor gene [56]. Inactivation of this gene by methylation was seen in HNSCC $[16,57]$. Several studies showed a range of $32 \%$ to $61.8 \%$ methylation of this gene in tumour tissues of HNSCC patients [17, 33, 35, 58]. Our results showed tumour tissue with significantly higher methylation compared to the surgical margin ( $57 \%$ vs $25 \%$ p $<0.001)$. Another study supported this finding [34,35], but other investigators did not show significant differences in promoter methylation between cases of oral cancer and normal control tissue $[17,33]$. Chang at al. showed hypermethylated promoters of E-cadherin in $64 \%$ of oral carcinoma cases, and downregulation of its expression was found to be related to promoter hypermethylation [59]. The influence of $C D H 1$ promoter methylation in the invasive progression of HNSCC was observed based on an increased frequency of gene methylation at stages beyond the early tumour stage [60]. Oral leucoplakia patients also showed a high percentage of methylation, which can be considered as a diagnostic marker [58]. Šupić et al. showed that patients with advanced oral squamous cell carcinoma with E-cad promoter methylation had significantly worse overall survival, and this factor can be proposed as a potential molecular marker for poor survival [36]. In other research, no differences between patients with HNSCC and a healthy control population regarding methylation of $C D H 1$ was observed; surprisingly, this gene was frequently methylated in control samples [45]. Using human carcinoma and fibroblast cell lines, Youshiura et al. investigated silencing of E-cadherin and postulated hypermethylation as a mechanism of inactivation. Furthermore, demethylating agents can be used in therapies as epigenetic drugs [56].

CpG Island Methylator Phenotype (CIMP) has been reported in cancer and was first described in colorectal cancer as a phenotype that includes methylation of multiple genes [61]. CIMP status was also observed and classified in HNSCC and indicated a correlation between environmental factors and CIMP in tumour tissue. Smoking was strong associated with CIMP-positivity compared to CIMP-negativity, and poor survival was associated with CIMP-positivity (five or more methylated genes) [35]. In our study, aberrant promoter hypermethylation was found in all five genes (CIMP-positive) in four cases $(5.3 \%)$ of tumour samples.

Our results based on correlations between aberrant methylation and patient's characteristics indicated that positive nodal status was related to a higher methylation rate of the APC and TIMP3 genes. 
We also noted that an advanced tumour stage was related to higher rates of methylation of the MGMT gene, supporting a role for gene methylation in the invasive progression of HNSCC. There is increasing evidence that methylation of specific genes is related with tumour biology, such as prognosis and drug response, and is linked with particular tumour histological features [62].

We also observed that the female gender showed a trend towards a lower recurrence rate. Furthermore, female gender conferred an increased methylation level of CDH1 and TIMP3 but with a decreased MGMT gene methylation level. Based on our results, it is unclear why gender influences methylation status. Other studies showed that dietary components can influence gene expression through epigenetic mechanisms $[63,64]$. Notably, methylation differences related to coffee consumption were observed only in women who never used menopausal hormone therapy (MHT) and suggest that coffee may affect DNA methylation levels in immune cells of the blood [65]. It is also suggested that oestrogen receptor alpha (ERa) may regulate gene expression partially via DNA methylation [66].

Furthermore, in our cohort of patients those with a family history of cancer showed more frequently methylated MGMT genes. Some studies indicated that a positive family history of cancer increases the risk of HNSCC cancer [67, 68]. A connection between the presence of methylation and a family history of cancer was also shown previously, indicating a shared aetiology such as genetic predisposition [46]. It is well known that environmental noise exposure can induce changes in DNA methylation and is connected with many human diseases [69]. Our results suggested that habitual factors associated with cigarettes confer higher methylation of the $A P C$ and $C D H 1$ genes. However, our patients with a history of abusing alcohol showed lower promoter methylation of the MGMT gene in the surgical margin. Numerous studies describe genes, including MGMT, that are frequently methylated due to smoking [24, 32, 70-74]. It is postulated that tobacco-specific nitrosamines prevalent in tobacco cause hypermethylation of genes [73]. It is difficult to explain how alcohol protects from methylation of genes involved in the DNA repair process. These results are unclear, but in tumour samples of squamous cell carcinoma of the head and neck there was an effect of alcohol use on gene hypermethylation [24, 60, 75]. There is also evidence that epigenetic mechanisms such as DNA methylation play a crucial role in the pathophysiology of alcoholism [76]. Multiple studies have shown alcohol-associated changes to DNA methylation which are complex and depend on numerous factors including gender and tissue type [77]. Pierini et al. noticed that intensive alcohol consumption is inversely associated with methylation of only one gene out of four analysed, suggesting that alcohol exposure might affect DNA methylation in a gene-specific manner [40]. Other findings have shown no correlation between methylation and cigarette smoking and alcohol intake [30, 40, 49, 50]. Contrary and obscure results were shown by Puri et al.: the promoter of the MGMT gene was hypermethylated in patients with a history of alcohol use but this was significantly associated with lack of hypermethylation in another gene studied, $p 16$ [12]. Because a high level of MGMT caused failure of therapy, it is noteworthy that expression of the MGMT gene imparted drug resistance of cancer cells to very popular classes of chemotherapeutic and chloroethylating agents [47, 48]. Moreover, methylation of MGMT not only led to sensitivity to alkylating drugs used in chemotherapy, but also exposed a mutator phenotype [62]. Polymorphisms of genes vulnerable to environmental carcinogens were especially common in those coding for enzymes involved in carcinogen metabolism, such as MGMT, as a mechanism for differential cancer susceptibility [78]. In a study by Huang et al. alcohol-related head and neck cancer risks tended to vary with MGMT genotypes [79]. An MGMT Ile143Val polymorphism may play a role in modulating the risk of cancer in the presence of alcohol [80]. Further studies are required to clarify these interactions of genetics and environmental factors.

Aberrant methylation profiles could be caused by various factors including the above-mentioned tobacco and alcohol consumption and also Human Papilloma Virus (HPV) infection [54, 57]. HPV-positive cancers have been shown to have elevated levels of methylation in the same regions of the genome [81]. TIMP3 was more hypermethylated in HPV-positive than in HPV-negative patients with oropharyngeal squamous cell carcinoma [54]. In addition to HPV, especially HPV type 16, as a cause of cancers of the head and neck [82], Helicobacter pylori was detected in the oropharyngeal area, leading to hypotheses about its participation in the development of cancer [83], although this result has not been confirmed. We plan to study HPV infection in our group of patients.

Our results showed aberrant DNA methylation both in tumour and surgical margins, which might be due to the existence of a heterogeneous preneoplastic field that is not detectable by basic histologic analysis and ipso facto revealing the impact of DNA aberrant methylation in tumorigenesis. Several cancers are known to display a "field effect" region outside the 
tumour border that harbours histological or molecular changes associated with cancer [84]. The initial step of a field effect is associated with various molecular lesions. The genetically altered mucosa that remains after therapy can cause local recurrences and second primary tumours after surgery to remove the primary carcinoma $[85,86]$. This process arises from exposure to harmful environmental factors such as alcohol and tobacco and is related to $75 \%$ of all squamous cell carcinomas of the head and neck [1]. Interestingly, research by Tan et al. and Hayashi et al. studied gene methylation in negative surgical margins in HNSCC; methylation was associated with decreased survival, and the researchers concluded that these analyses served as predictive markers of postoperative locoregional recurrence [18, 87]. Importantly, epigenetic aberration was also found in histologically normal mammary tissues [88]. Similar suggestions based on results indicating hypermethylation of tumour suppressor genes in control populations as a consequence of environmental factors were made by Carvalho et al. [16]. Increased DNA methylation is also associated with ageing and chronic inflammation [62].

Some authors describe a "molecular surgical margin" (MSM), whose status is estimated not only by histopathologic assessment but also by the presence of molecular markers; this MSM could allow more accurate assessment of cancer recurrence. Moreover, in surgical practice, particularly regarding the head and neck, the problem is to completely remove collateral areas because any remaining cells with molecular abnormalities increase the risk of developing a second primary tumour [89].

Taken together, access to molecular biology methods has allowed recently for the precise analysis of the genetic material, but at the same time the complexity of the physiological and pathophysiological processes often make it difficult to interpret the results. More precise methods of cancer treatment depend on advances in basic research. The diagnosis and treatment of cancer should focus on the field of origin, and not only on the tumour [90].

\section{Conclusions}

Based on our observations, aberrant methylation is an important epigenetic event in HNSCC cancer. The hypermethylation of the promoter region of the MGMT and CDH1 genes could be a potential biomarker in HNSCC cancer. Moreover, clinical and habitual factors affect methylation in different manners and cause different patterns of gene promoter methylation. Our observations confirm the presence of epigenetic changes not only in the cancer cells but also in the surrounding mucosa, and represent a basis for the suggestion that appropriate cancer risk assessment based on epigenetic alterations in surgical margins may influence a patient's diagnosis and cure.

\section{Abbreviations}

HNSCC: head and neck squamous cell carcinoma; MSP: methylation-specific polymerase chain reaction; CIMP: CpG Island Methylator Phenotype APC: Adenomatous Polyposis Coli; MGMT: O6-methylguanine-DNA methyltransferase; TIMP3: tissue inhibitor of metalloproteinase-3; HPV: human papilloma virus.

\section{Acknowledgments}

We would like to thank Professor Andrzej Wiczkowski for advice on the design of this study and Ms. Anna Plachetka, MS, for help with performing the analysis.

\section{Author Contributions}

Joanna Katarzyna Strzelczyk: conception and design of the study, acquisition of data, performing the analyses, analysis and interpretation of data, drafting the article, final approval of the version to be submitted, agreement to be accountable for all aspects of the work in ensuring that questions related to the accuracy or integrity of any part of the work are appropriately investigated and resolved.

Łukasz Krakowczyk: acquisition and interpretation of data, revising work critically for important intellectual content, final approval of the version to be submitted, agreement to be accountable for all aspects of the work in ensuring that questions related to the accuracy or integrity of any part of the work are appropriately investigated and resolved.

Aleksander Jerzy Owczarek: analysis and interpretation of data, revising work critically for important intellectual content, final approval of the version to be submitted, agreement to be accountable for all aspects of the work in ensuring that questions related to the accuracy or integrity of any part of the work are appropriately investigated and resolved.

\section{Competing Interests}

The authors have declared that no competing interest exists.

\section{References}

1. Argiris A, Karamouzis MV, Raben D, et al. Head and neck cancer. Lancet. 2008; 371(9625): 1695-709. doi: 10.1016/S0140-6736(08)60728-X.

2. Wyss A, Hashibe M, Chuang SC, et al. Cigarette, cigar, and pipe smoking and the risk of head and neck cancers: pooled analysis in the International Head and Neck Cancer Epidemiology Consortium. Am J Epidemiol. 2013; 178(5): 679-90. doi: 10.1093/aje/kwt029.

3. Blot WJ, McLaughlin JK, Winn DM, et al. Smoking and drinking in relation to oral and pharyngeal cancer. Cancer Res. 1988; 48(11): 3282-7. 
4. Kerishnan JP, Gopinath SC, Kai SB, et al. Detection of Human Papillomavirus 16-Specific IgG and IgM Antibodies in Patient Sera: A Potential Indicator of Oral Squamous Cell Carcinoma Risk Factor. Int J Med Sci. 2016; 13(6): 424-31. doi: $10.7150 /$ ijms.14475.

5. Leemans CR, Braakhuis BJ, Brakenhoff RH. The molecular biology of head and neck cancer. Nat Rev Cancer. 2011; 11(1): 9-22. doi: 10.1038/nrc2982.

6. Baylin SB, Ohm JE. Epigenetic gene silencing in cancer - a mechanism for early oncogenic pathway addiction? Nat Rev Cancer. 2006; 6(2): 107-16.

7. Ushijima T, Nakajima T, Maekita T. DNA methylation as a marker for the past and future. J Gastroenterol. 2006; 41(5): 401-7.

8. Esteller M, Hamilton SR, Burger PC, et al. Inactivation of the DNA repair gene O6-methylguanine-DNA methyltransferase by promoter hypermethylation is a common event in primary human neoplasia. Cancer Res. 1999; 59(4): 793-7.

9. Burri N, Shaw P, Bouzourene $\mathrm{H}$, et al. Methylation silencing and mutations of the p14ARF and p16INK4a genes in colon cancer. Lab Invest. 2001; 81(2): 217-29.

10. Massie CE, Mills IG, Lynch AG. The importance of DNA methylation in prostate cancer development. J Steroid Biochem Mol Biol. 2017; 166: 1-15. doi: 10.1016/j.jsbmb.2016.04.009.

11. Paska AV, Hudler P. Aberrant methylation patterns in cancer: a clinical view. Biochem Med (Zagreb). 2015; 25(2): 161-76. doi: 10.11613/BM.2015.017.

12. Puri SK, Si L, Fan CY, et al. Aberrant promoter hypermethylation of multiple genes in head and neck squamous cell carcinoma. Am J Otolaryngol. 2005; 26(1): $12-7$.

13. Nagata $\mathrm{S}$, Hamada $\mathrm{T}$, Yamada $\mathrm{N}$, et al. Aberrant DNA methylation of tumor-related genes in oral rinse: a noninvasive method for detection of oral squamous cell carcinoma. Cancer. 2012; 118(17): 4298-308. doi: $10.1002 /$ cncr. 27417.

14. Kwong J, Lo KW, To KF, et al. Promoter hypermethylation of multiple genes in nasopharyngeal carcinoma. Clin Cancer Res. 2002; 8(1): 131-7.

15. Rettori $\mathrm{MM}$, de Carvalho $\mathrm{AC}$, Longo $\mathrm{AL}$, et al. TIMP3 and CCNA1 hypermethylation in HNSCC is associated with an increased incidence of second primary tumors. J Transl Med. 2013; 11: 316. doi: 10.1186/1479-5876-11-316.

16. Carvalho AL, Jeronimo $\mathrm{C}$, Kim $\mathrm{MM}$, et al. Evaluation of promoter hypermethylation detection in body fluids as a screening/diagnosis tool for head and neck squamous cell carcinoma. Clin Cancer Res. 2008; 14(1): 97-107. doi: 10.1158/1078-0432.CCR-07-0722.

17. Kordi-Tamandani DM, Moazeni-Roodi AK, Rigi-Ladiz MA, et al. Promoter hypermethylation and expression profile of MGMT and CDH1 genes in oral cavity cancer. Arch Oral Biol. 2010; 55(10): 809-14. doi:10.1016/j.archoralbio.2010.06.017.

18. Tan HK, Saulnier P, Auperin A, et al. Quantitative methylation analyses of resection margins predict local recurrences and disease-specific deaths in patients with head and neck squamous cell carcinomas. Br J Cancer. 2008; 99(2): 357-63. doi:10.1038/sj.bjc.6604478.

19. Martone T, Gillio-Tos A, De Marco L, et al. Association between hypermethylated tumor and paired surgical margins in head and neck squamous cell carcinomas. Clin Cancer Res. 2007; 13(17): 5089-94.

20. Xiao C, Wang L, Zhu L, et al. Secreted frizzled-related protein 2 is epigenetically silenced and functions as a tumor suppressor in oral squamous cell carcinoma. Mol Med Rep. 2014; 10(5): 2293-8. doi: 10.3892/mmr.2014.2542.

21. Miyakura Y, Tahara M, Lefor AT, et al. Haplotype defined by the MLH1-93G/A polymorphism is associated with MLH1 promoter hypermethylation in sporadic colorectal cancers. BMC Res Notes. 2014; 7: 835. doi:10.1186/1756-0500-7-835.

22. Dorri F, Mendelowitz L, Corrada Bravo H. methylFlow: cell-specific methylation pattern reconstruction from high-throughput bisulfite-converted DNA sequencing. Bioinformatics. 2016; 32(11): 1618-24. doi: 10.1093/bioinformatics/btw287.

23. Herman JG, Graff JR, Myöhänen S, et al. Methylation-specific PCR: a novel PCR assay for methylation status of CpG islands. Proc Natl Acad Sci USA. 1996; 93(18): 9821-6.

24. Wong TS, Man MW, Lam AK, et al. The study of p16 and p15 gene methylation in head and neck squamous cell carcinoma and their quantitative evaluation in plasma by real-time PCR. Eur J Cancer. 2003; 39(13): 1881-7.

25. Wang P, Pei R, Lu Z, et al. Methylation of p16 CpG islands correlated with metastasis and aggressiveness in papillary thyroid carcinoma. J Chin Med Assoc. 2013; 76(3): 135-9. doi: 10.1016/j.jcma.2012.11.007.

26. Righini CA, de Fraipont F, Timsit JF, et al. Tumor-specific methylation in saliva: a promising biomarker for early detection of head and neck cancer recurrence. Clin Cancer Res. 2007; 13(4): 1179-85.

27. Shilpa V, Bhagat R, Premalata CS, et al. Relationship between promoter methylation \& tissue expression of MGMT gene in ovarian cancer. Indian J Med Res. 2014; 140(5): 616-23.

28. Esteller M, Corn PG, Baylin SB, et al. A gene hypermethylation profile of human cancer. Cancer Res. 2001; 61(8): 3225-9.

29. Kaur J, Demokan S, Tripathi SC, et al. Promoter hypermethylation in Indian primary oral squamous cell carcinoma. Int J Cancer. 2010; 127(10): 2367-73. doi: $10.1002 /$ ijc. 25377

30. Kato K, Hara A, Kuno T, et al. Aberrant promoter hypermethylation of p16 and MGMT genes in oral squamous cell carcinomas and the surrounding normal mucosa. J Cancer Res Clin Oncol. 2006; 132(11): 735-43.
31. Sinha P, Bahadur S, Thakar A, et al. Significance of promoter hypermethylation of p16 gene for margin assessment in carcinoma tongue. Head Neck. 2009; 31(11): 1423-30. doi: 10.1002/hed.21122.

32. Bhatia V, Goel MM, Makker A, et al. Promoter region hypermethylation and mRNA expression of MGMT and p16 genes in tissue and blood samples of human premalignant oral lesions and oral squamous cell carcinoma. Biomed Res Int. 2014; 2014: 248419. doi:10.1155/2014/248419.

33. Shaw RJ, Liloglou T, Rogers SN, et al. Promoter methylation of P16, RARbeta, E-cadherin, cyclin A1 and cytoglobin in oral cancer: quantitative evaluation using pyrosequencing. Br J Cancer. 2006; 94(4): 561-8.

34. Su PF, Huang WL, Wu HT, et al. p16INK4A promoter hypermethylation is associated with invasiveness and prognosis of oral squamous cell carcinoma in an age-dependent manner. Oral Oncol. 2010; 46(10): 734-739. doi:org/10.1016/j.oraloncology.2010.07.002.

35. Choudhury JH, Ghosh SK. Promoter Hypermethylation Profiling Identifies Subtypes of Head and Neck Cancer with Distinct Viral, Environmental, Genetic and Survival Characteristics. PLoS One. 2015; 10(6): e0129808. doi:10.1371/journal.pone.0129808.

36. Šupić G, Kozomara R, Branković-Magić M, et al. Gene hypermethylation in tumor tissue of advanced oral squamous cell carcinoma patients. Oral Oncol. 2009; 45(12): 1051-1057. doi:org/10.1016/j.oraloncology.2009.07.007.

37. Demokan S, Dalay N. Role of DNA methylation in head and neck cancer. Clin Epigenetics. 2011; 2(2): 123-50. doi: 10.1007/s13148-011-0045-3.

38. Noorlag R, van Kempen PM, Moelans CB, et al. Promoter hypermethylation using 24-gene array in early head and neck cancer: better outcome in oral than in oropharyngeal cancer. Epigenetics. 2014; 9(9): 1220-7. doi: 10.4161/epi.29785.

39. Ishida E, Nakamura M, Ikuta M, et al. Promotor hypermethylation of p14ARF is a key alteration for progression of oral squamous cell carcinoma. Oral Oncol. 2005; 41(6): 614-22.

40. Pierini S, Jordanov SH, Mitkova AV, et al. Promoter hypermethylation of CDKN2A, MGMT, MLH1, and DAPK genes in laryngeal squamous cell carcinoma and their associations with clinical profiles of the patients. Head Neck. 2014; 36(8): 1103-8. doi:10.1002/hed.23413.

41. Al-Kaabi A, van Bockel LW, Pothen AJ, et al. p16INK4A and p14ARF gene promoter hypermethylation as prognostic biomarker in oral and oropharyngeal squamous cell carcinoma: a review. Dis Markers. 2014; 2014: 260549. doi: $10.1155 / 2014 / 260549$.

42. Gasche JA, Goel A. Epigenetic mechanisms in oral carcinogenesis. Future Oncol. 2012; 8(11): 1407-25. doi: 10.2217/fon.12.138

43. Gao S, Eiberg H, Krogdahl A, et al. Cytoplasmic expression of E-cadherin and beta-Catenin correlated with $\mathrm{LOH}$ and hypermethylation of the APC gene in oral squamous cell carcinomas. J Oral Pathol Med. 2005; 34(2): 116-9.

44. Šupić G, Kozomara R, Jovic N, et al. Prognostic significance of tumor-related genes hypermethylation detected in cancer-free surgical margins of oral squamous cell carcinomas. Oral Oncol. 2011; 47(8): 702-708.

45. Longo AL, Rettori MM, de Carvalho AC, et al. Evaluation of the methylation profile of exfoliated cell samples from patients with head and neck squamous cell carcinoma. Head Neck. 2014; 36(5): 631-7. doi:10.1002/hed. 23345.

46. Brait M, Ford JG, Papaiahgari S, et al. Association between lifestyle factors and CpG island methylation in a cancer-free population. Cancer Epidemiol Biomarkers Prev. 2009; 18(11): 2984-91. doi: 10.1158/1055-9965.EPI-08-1245.

47. Sharma S, Salehi F, Scheithauer BW, et al. Role of MGMT in tumor development, progression, diagnosis, treatment and prognosis. Anticancer Res. 2009; 29(10): 3759-68.

48. Gerson SL. Clinical relevance of MGMT in the treatment of cancer. J Clin Oncol. 2002; 20(9): 2388-99.

49. Paluszczak J, Misiak P, Wierzbicka M, et al. Frequent hypermethylation of DAPK, RARbeta, MGMT, RASSF1A and FHIT in laryngeal squamous cell carcinomas and adjacent normal mucosa. Oral Oncol. 2011; 47(2): 104-7. doi: 10.1016/j.oraloncology.2010.11.006.

50. Taioli E, Ragin C, Wang XH, et al. Recurrence in oral and pharyngeal cancer is associated with quantitative MGMT promoter methylation. BMC Cancer. 2009; 9: 354. doi:10.1186/1471-2407-9-354.

51. Darnton SJ, Hardie LJ, Muc RS, et al. Tissue inhibitor of metalloproteinase-3 (TIMP-3) gene is methylated in the development of esophageal adenocarcinoma: loss of expression correlates with poor prognosis. Int J Cancer. 2005; 115(3): 351-8

52. Bachman KE, Herman JG, Corn PG, et al. Methylation-associated silencing of the tissue inhibitor of metalloproteinase-3 gene suggest a suppressor role in kidney, brain, and other human cancers. Cancer Res. 1999; 59(4): 798-802.

53. van Kempen PM, Noorlag R, Braunius WW, et al. Differences in methylation profiles between HPV-positive and HPV-negative oropharynx squamous cell carcinoma: a systematic review. Epigenetics. 2014; 9(2): 194-203. doi: 10.4161/epi.26881.

54. van Kempen PM, van Bockel L, Braunius WW, et al. HPV-positive oropharyngeal squamous cell carcinoma is associated with TIMP3 and CADM1 promoter hypermethylation. Cancer Med. 2014; 3(5): 1185-96. doi: $10.1002 /$ cam 4.313

55. Arantes LM, de Carvalho AC, Melendez ME, et al. Validation of methylation markers for diagnosis of oral cavity cancer. Eur J Cancer. 2015; 51(5): 632-41. doi: 10.1016/j.ejca.2015.01.060.

56. Yoshiura $\mathrm{K}$, Kanai $\mathrm{Y}$, Ochiai $\mathrm{A}$, et al. Silencing of the E-cadherin invasion-suppressor gene by $\mathrm{CpG}$ methylation in human carcinomas. Proc Natl Acad Sci USA. 1995; 92(16): 7416-9. 
57. Wong TS, Gao W, Chan JY. Interactions between E-cadherin and microRNA deregulation in head and neck cancers: the potential interplay. Biomed Res Int. 2014; 2014: 126038. doi: 10.1155/2014/126038.

58. Asokan GS, Jeelani S, Gnanasundaram N. Promoter hypermethylation profile of tumour suppressor genes in oral leukoplakia and oral squamous cell carcinoma. J Clin Diagn Res. 2014; 8(10): ZC09-12. doi: 10.7860/JCDR/2014/9251.4949.

59. Chang HW, Chow V, Lam KY, et al. Loss of E-cadherin expression resulting from promoter hypermethylation in oral tongue carcinoma and its prognostic significance. Cancer. 2002; 94(2): 386-92.

60. Shen Z, Zhou C, Li J, et al. The association, clinicopathological significance, and diagnostic value of $\mathrm{CDH} 1$ promoter methylation in head and neck squamous cell carcinoma: a meta-analysis of 23 studies. Onco Targets Ther. 2016; 9: 6763-6773.

61. Ushijima T, Watanabe $\mathrm{N}$, Shimizu $\mathrm{K}$, et al. Decreased fidelity in replicating CpG methylation patterns in cancer cells. Cancer Res. 2005 Jan 1;65(1): 11-7.

62. Ushijima T, Okochi-Takada E. Aberrant methylations in cancer cells: where do they come from? Cancer Sci. 2005; 96(4): 206-11.

63. Šupić G, Jagodic M, Magić Z. Epigenetics: a new link between nutrition and cancer. Nutr Cancer. 2013; 65(6): 781-92. doi: 10.1080/01635581.2013.805794.

64. McKee SE, Grissom NM, Herdt CT, et al. Methyl donor supplementation alters cognitive performance and motivation in female offspring from high-fat diet-feddams. FASEB J. 2017; 31(6): 2352-2363. doi: 10.1096/fj.201601172R.

65. Chuang $\mathrm{YH}$, Quach A, Absher D, et al. Coffee consumption is associated with DNA methylation levels of human blood. Eur J Hum Genet. 2017; 25(5): 608-616. doi: 10.1038/ejhg.2016.175.

66. Ariazi EA, Taylor JC, Black MA, et al. A New Role for ERa: Silencing via DNA Methylation of Basal, Stem Cell, and EMT Genes. Mol Cancer Res. 2017; 15(2): 152-164. doi: 10.1158/1541-7786.MCR-16-0283.

67. Garavello W, Turati F, Bosetti C, et al. Family history of cancer and the risk of laryngeal cancer: a case-control study from Italy and Switzerland. Int J Cancer. 2012; 130(3): 665-70. doi: 10.1002/ijc.26055.

68. Copper MP, Jovanovic A, Nauta JJ, et al. Role of genetic factors in the etiology of squamous cell carcinoma of the head and neck. Arch Otolaryngol Head Neck Surg. 1995; 121(2): 157-60.

69. Guo L, Li PH, Li H, et al. Effects of environmental noise exposure on DNA methylation in the brain and metabolic health. Environ Res. 2017; 153: 73-82. doi: 10.1016/j.envres.2016.11.017.

70. Rosas SL, Koch W, da Costa Carvalho MG, et al. Promoter hypermethylation patterns of p16, O6-methylguanine-DNA-methyltransferase, and death-associated protein kinase in tumors and saliva of head and neck cancer patients. Cancer Res. 2001; 61(3): 939-42.

71. Zeilinger S, Kühnel B, Klopp N, et al. Tobacco smoking leads to extensive genome-wide changes in DNA methylation. PLoS One. 2013; 8(5): e63812. doi: 10.1371/journal.pone.0063812.

72. Belinsky SA, Liechty KC, Gentry FD, et al. Promoter hypermethylation of multiple genes in sputum precedes lung cancer incidence in a high-risk cohort. Cancer Res. 2006; 66(6): 3338-44

73. Das M, Sharma SK, Sekhon GS, et al. Promoter methylation of MGMT gene in serum of patients with esophageal squamous cell carcinoma in North East India. Asian Pac J Cancer Prev. 2014; 15(22): 9955-60.

74. Díez-Pérez R, Campo-Trapero J, Cano-Sánchez J, et al. Methylation in oral cancer and pre-cancerous lesions (Review). Oncol Rep. 2011; 25(5): 1203-9. doi:10.3892/or.2011.1205.

75. Misawa K, Mochizuki D, Imai A, et al. Prognostic value of aberrant promoter hypermethylation of tumor-related genes in early-stage head and neck cancer. Oncotarget. 2016; 7(18): 26087-98. doi: 10.18632/oncotarget.8317.

76. Auta J, Zhang H, Pandey SC, et al. Chronic Alcohol Exposure Differentially Alters One-Carbon Metabolism in Rat Liver and Brain. Alcohol Clin Exp Res. 2017; 41(6): 1105-11. doi: 10.1111/acer.13382.

77. Tulisiak CT, Harris RA, Ponomarev I. DNA modifications in models of alcohol use disorders. Alcohol. 2017; 60: 19-30. doi: 10.1016/j.alcohol.2016.11.004

78. Kaur TB, Travaline JM, Gaughan JP, et al. Role of polymorphisms in codons 143 and 160 of the O6-alkylguanine DNA alkyltransferase gene in lung cancer risk. Cancer Epidemiol Biomarkers Prev. 2000; 9(3): 339-42.

79. Huang WY, Olshan AF, Schwartz SM, et al. Selected genetic polymorphisms in MGMT, XRCC1, XPD, and XRCC3 and risk of head and neck cancer: a pooled analysis. Cancer Epidemiol Biomarkers Prev. 2005; 14(7): 1747-53.

80. Loh YH, Mitrou PN, Bowman R, et al. MGMT Ile143Val polymorphism, dietary factors and the risk of breast, colorectal and prostate cancer in the European Prospective Investigation into Cancer and Nutrition (EPIC)-Norfolk study. DNA Repair (Amst). 2010; 9(4): 421-8. doi: 10.1016/j.dnarep.2010.01.002

81. Lindsay C, Seikaly H, Biron VL. Epigenetics of oropharyngeal squamous cell carcinoma: opportunities for novel chemotherapeutic targets. J Otolaryngol Head Neck Surg. 2017; 46(1): 9. doi: 10.1186/s40463-017-0185-3.

82. Mork J, Lie AK, Glattre E, et al. Human papillomavirus infection as a risk factor for squamous-cell carcinoma of the head and neck. N Engl J Med. 2001; 344(15): 1125-31.

83. Pavlik E, Nartova E, Astl J, et al. Detection of Helicobacter pylori and Human Papillomavirus in Peroperative Tissue Biopsies Collected from Malignancies in Oropharyngeal Area. Am J Clin Exp Med 2015; 3: 364-367.

84. Risk MC, Knudsen BS, Coleman I, et al. Differential gene expression in benign prostate epithelium of men with and without prostate cancer: evidence for a prostate cancer field effect. Clin Cancer Res. 2010; 16(22): 5414-23. doi:10.1158/1078-0432.CCR-10-0272.

85. Tabor MP, Brakenhoff RH, van Houten VM, et al. Persistence of genetically altered fields in head and neck cancer patients: biological and clinical implications. Clin Cancer Res. 2001; 7(6): 1523-32.

86. Angadi PV, Savitha JK, Rao SS, et al. Oral field cancerization: current evidence and future perspectives. Oral Maxillofac Surg. 2012; 16(2): 171-80. doi: 10.1007/s10006-012-0317-x.

87. Hayashi M, Wu G, Roh JL, et al. Correlation of gene methylation in surgical margin imprints with locoregional recurrence in head and neck squamous cell carcinoma. Cancer. 2015; 121(12): 1957-65. doi:10.1002/cncr.29303.

88. Heaphy CM, Griffith JK, Bisoffi M. Mammary field cancerization: molecular evidence and clinical importance. Breast Cancer Res Treat. 2009; 118(2):229-39. doi: 10.1007/s10549-009-0504-0.

89. Mao L, Clark D. Molecular margin of surgical resections - Where do we go from here? Cancer. 2015; 121: 1914-1916.

90. Braakhuis BJ, Tabor MP, Kummer JA, et al. A genetic explanation of Slaughter's concept of field cancerization: evidence and clinical implications. Cancer Res. 2003; 63(8): 1727-30. 